\title{
Influences of Domestication and Island Evolution on Dental Growth in Sheep
}

\author{
Madeleine Geiger $^{1}$ (D) $\cdot$ Sinead Marron ${ }^{1} \cdot$ Abagael R. West $^{2} \cdot$ Robert J. Asher $^{1}$
}

Published online: 29 October 2018

(C) The Author(s) 2018

\begin{abstract}
Domestication and island evolution can lead to changes of life history along the slow-fast gradient. Shifts of life history patterns, in turn, are potentially related to alterations of patterns and timing of tooth eruption. Schultz's rule predicts an earlier eruption of molars relative to premolars as fecundity increases during the domestication process. On the other hand, evolution on a predatorfree, resource limited island might lead to a generally slow life history and delayed tooth eruption, as in the Plio-Pleistocene Balearic caprine Myotragus. In this study, we investigate tooth eruption and its relation to life history in a unique sheep population that is an example of both domestication and island evolution: the ancient and feral Soay sheep (Ovis aries) of the St. Kilda archipelago, Scotland. Tooth eruption timing and sequence is investigated in a comparative framework featuring new data on other domestic sheep (O. aries), including European mouflon (O. a. musimon), as well as wild sheep (O. vignei, O. cycloceros, $O$. arkal, O. orientalis, $O$. ammon). These data indicate that the order of eruption is similar in wild and domestic sheep, despite the fundamental life history changes that came about with domestication. However, in contrast to other domestic sheep breeds, Soay sheep erupt their teeth at an absolute older age and also tend to grow more slowly, which resembles the evolutionary trend in island-adapted Myotragus. Despite these similarities, Soay sheep do not share the slow life history pattern inferred for Myotragus, highlighting the distinctive nature of tooth eruption in Soay sheep.
\end{abstract}

Keywords Tooth eruption $\cdot$ Ovis $\cdot$ Schultz's rule $\cdot$ Soay sheep

\section{Introduction}

Populations evolving on islands experience special environmental conditions and selection pressures not usually present on the mainland. These include a founder effect, a lack of predator pressure, low interspecific competition, and high intraspecific competition (see e.g., Sondaar 1977 and van der Geer et al. 2010 for detailed reviews). Domestication, a selection process for adaptation to human ecological niches (e.g.,

Electronic supplementary material The online version of this article (https://doi.org/10.1007/s10914-018-9452-y) contains supplementary material, which is available to authorized users.

Madeleine Geiger

madeleine.geiger87@gmail.com

1 Department of Zoology, University of Cambridge, Downing St, Cambridge CB2 3EJ, UK

2 Section of Vertebrate Paleontology \& Section of Mammals, Carnegie Museum of Natural History, 4400 Forbes Avenue, Pittsburgh, PA 15213, USA
Larson et al. 2014), resembles selection pressures on islands (Sánchez-Villagra et al. 2016). Some of the phenotypic alterations that result from such selection pressures are similar in island and domestic mammals, e.g., increased size variation and shortening of limbs (Sánchez-Villagra et al. 2016). Other phenotypic results from island vs. domestication selection are different. For example, life history accelerates as a result of domestication (Tchernov and Horwitz 1991), whereas this does not consistently occur among island mammals. There are two major contrasting models of life history evolution on islands (Reznick et al. 2002; Köhler and Moyà-Sola 2009). First, resources on islands can be limited, potentially leading to adaptations towards energy saving and thus reduced rates of growth and 'slow' life history (e.g., Palkovacs 2003). In other cases, the absence of predators and competitors from an island may lead to selection for faster growth and life history, e.g., earlier sexual maturity (e.g., Raia et al. 2003).

Changes of life history and variables such as body and brain size have been found to correlate with changes in the pattern and the timing of tooth eruption in some mammals (Smith 2000; Godfrey et al. 2001). There is evidence in some 
mammals for a phenomenon termed 'Schultz's rule', which describes the trend of an increasing number of replacement teeth (incisors, canines, premolars) erupting simultaneously with or before the molars when development and life history are 'slow', i.e., slow growth, late sexual maturity, long gestation, and extended longevity (Schultz 1956, 1960; Smith 2000). In other words, slow-growing species have a prolonged juvenile phase, and to prevent the deciduous teeth from wearing out before the permanent teeth become functional in a jaw that is not yet large enough to contain all molars, the replacement teeth erupt relatively early (see also Godfrey et al. 2005). Alternatively (or additionally), a prolonged lifespan makes necessary the relatively later eruption of molars to keep the dentition functional during an extended lifespan (see also Janis and Fortelius 1988). Evidence for Schultz's rule has been found in primates and 'ungulates' (Smith 2000) and platyrrhine primates (Henderson 2007), whereas evidence is ambiguous for many artiodactyls (Monson and Hlusko 2016; Veitschegger and Sánchez-Villagra 2016), some primates (Godfrey et al. 2005; Schwartz et al. 2005; Guthrie and Frost 2011; Jogahara and Natori 2012), and hyraxes (Asher et al. 2017). Concerning the absolute timing of tooth eruption, various hypotheses suggest relations to body size, brain size, period of learning, resource availability, and diet and its protein content (for an extensive review see Godfrey et al. 2001). Specifically, it has been suggested that in an environment where the risk of starvation is high, slow dental growth would be beneficial because it reduces caloric need per unit time (Godfrey et al. 2001).

One well investigated example of island evolution is the Balearic mouse-goat (Myotragus), a small Ovis-relative from the Plio-Pleistocene of the Balearic Islands (Spain) (LaluezaFox et al. 2005), which exhibits a set of unusual apomorphies (e.g., Köhler and Moyà-Solà 2004; van der Geer et al. 2010). For example, Myotragus had a relatively small brain and sense organs (Köhler and Moyà-Solà 2004), had relatively short limbs (Sondaar 1977), grew seasonally and relatively slowly (Köhler and Moyà-Sola 2009), attained dental maturity relatively late (Jordana and Köhler 2011), had a relatively delayed weaning and first reproduction (Marín-Moratalla et al. 2011), and had an extended lifespan (Marín-Moratalla et al. 2011; Jordana et al. 2012), all relative to (mainly extant) mainland caprines. Therefore, the hypothetical ancestor of Myotragus presumably had a larger brain, grew faster, matured earlier somatically as well as sexually, and had a shorter lifespan, thus placing Myotragus towards the slow end of the fastslow continuum of life history (Jordana and Köhler 2011). In agreement with Schultz's rule, M. balearicus erupts its lower incisor and premolar early relative to the molars compared to continental caprines (Jordana et al. 2013). The relatively slow growth and development of Myotragus has been suggested to result from the relatively small island size and limited resources which, in conjunction with the absence of predators, can lead to overpopulation and subsequent starvation and population crashes (Sondaar 1977; Köhler and Moyà-Solà 2004).

The Soay sheep (Ovis aries) of the St. Kilda archipelago (beyond the Outer Hebrides, Scotland) (Boyd et al. 1964; Jewell et al. 1974; Clutton-Brock and Pemberton 2004b) is another example of an island caprine population, showing some parallel characteristics compared to Myotragus (Table 1). Soay sheep descend from a domesticated founder population and, like the European mouflon (O. a. musimon), probably stem from some of the first domesticated sheep in Europe (likely exceeding 4000 years in age), although there has probably been some admixture with modern breeds about 150 years ago (Boyd et al. 1964; Campbell 1974; Chessa et al. 2009; Feulner et al. 2013). Many aspects of the Soay sheep phenotype are intermediate between wild sheep (e.g., $O$. orientalis) and improved domestic sheep, i.e., modern breeds in which certain characteristics, e.g., wool quality or high reproductive performance, have been optimized by means of artificial selection and breeding (Boyd et al. 1964; Clutton-Brock et al. 2004b) (Table 2). Soay sheep have probably lived on St. Kilda over the past 3000-4000 years (Campbell 1974; Morton Boyd and Jewell 1974; CluttonBrock et al. 2004b; Clutton-Brock and Pemberton 2004a). Although the people inhabiting the island are known to have hunted the Soay sheep and harvested their wool into the 1930s, the sheep have not been managed or fed by humans for at least 70 years and can thus be considered feral (Boyd et al. 1964; Clutton-Brock et al. 2004b). There are no predators or competing herbivores on the islands (Campbell 1974) and the main cause of death is starvation, probably due to a combination of high sheep density, reduced plant growth during winter, delayed recovery of pastures in spring, and harsh winter weather, which in combination with a high parasitic nematode load, can lead to population crashes in some years (Milner and Gwynne 1974; Morton Boyd and Jewell 1974; Gulland 1992; Coulson et al. 2001; Clutton-Brock et al. 2004a, b; Wilson et al. 2004). Although the early onset of reproduction and great fecundity in Soay sheep (Table 2), even at peak population densities, may thus appear as a maladaptive heritage of domestication, this reproductive behavior appears to be close to optimal for maximizing the individual fitness (Morton Boyd and Jewell 1974; Stevenson et al. 2004). It is therefore possible that other aspects of the biology of Soay sheep are not just the legacy of domestication but adaptations to an island environment, as in Myotragus.

Schultz's rule predicts a later eruption of premolars compared to molars as a result of faster life history (greater fecundity) in domestic sheep compared to the wild forms (Table 2). Schultz's rule was originally defined as a trend towards earlier eruption of replacement teeth compared to the molars in increasingly slow maturing species to maximize the longevity of a functional dentition throughout an extended lifespan 
Table 1 Comparison between two island mammals, the extant Soay sheep (Ovis aries) and the Plio-Pleistocene Myotragus

\begin{tabular}{lll}
\hline Trait & Soay sheep (Ovis aries) & Myotragus \\
\hline Persistence time on island & $3000-4000$ years ${ }^{\mathrm{a}, \mathrm{b}}$ & 5.2 Million years $^{\mathrm{k}}$ \\
$\begin{array}{c}\text { Island area \& geographic } \\
\text { location (present) }\end{array}$ & $\begin{array}{c}6.7 \mathrm{~km}^{2} \text { (Hirta), St. Kilda, } \\
\text { Scotland }\end{array}$ & $\begin{array}{c}3640 \mathrm{~km}^{2} \text { (Mallorca), 694 } \mathrm{km}^{2} \\
\text { (Menorca), Baleares, Spain }\end{array}$ \\
$\begin{array}{ll}\text { Important mortality factor } \\
\text { Harsh climate, parasites, } \\
\text { resource depletion }^{\mathrm{c}}\end{array}$ & Resource depletion $^{\mathrm{k}}$ \\
Relative length of limbs & Shorter $^{\mathrm{d}}$ & Shorter $^{1}$ \\
Brain size & Similar $^{\mathrm{e}}$ & Smaller $^{\mathrm{k}}$ \\
Sexual maturity & Similar $^{\mathrm{b}}$ & Later $^{\mathrm{m}}$ \\
Longevity & Similar $^{\mathrm{f}, \mathrm{b}}$ & Longer $^{\mathrm{m}, \mathrm{n}}$ \\
Dental maturity & Later $^{\mathrm{g}, \mathrm{h}, \mathrm{i}, \mathrm{j}}$ & Later $^{\mathrm{o}}$ \\
Skeletal growth & Similar $^{\mathrm{d}} /$ slower $^{\mathrm{j}}$ & Slower $^{\mathrm{p}}$ \\
\hline
\end{tabular}

Comparisons of life history variables are in relation to the respective closest relatives, i.e., other domestic sheep in the case of Soay sheep and putative mainland relatives in the case of Myotragus. Bold font indicates similar characteristics in Soay sheep and Myotragus. Footnotes indicate references

${ }^{\text {a }}$ Clutton-Brock and Pemberton (2004a)

${ }^{\mathrm{b}}$ Clutton-Brock et al. (2004b)

${ }^{c}$ Clutton-Brock et al. (2004a)

d Clutton-Brock et al. (1990)

e Groves (1989)

${ }^{\mathrm{f}}$ Tacutu et al. (2013)

g Benzie and Gill (1974)

h Moran and O'Connor (1994)

i Jones (2002)

${ }^{\mathrm{j}}$ this study

k Köhler and Moyà-Solà (2004)

${ }^{1}$ Sondaar (1977)

${ }^{m}$ Marín-Moratalla et al. (2011)

n Jordana et al. (2012)

o Jordana and Köhler (2011)

p Köhler and Moyà-Sola (2009)
(Schultz 1956, 1960; Smith 2000). This trend could be reversed, e.g., when domestic animals attain sexual maturity earlier than their wild counterparts, imposing considerable energetic costs. Deciduous premolars in Ovis are relatively large (Habermehl 1975, 1985) and it might be beneficial to erupt the molars relatively earlier to increase the overall chewing surface, thus maximizing mastication potential as early in life as possible. Such variation of tooth eruption sequences between wild and domestic mammals has so far not been investigated. However, a similar process has been suggested for the evolutionary pattern of tooth eruption found in some notoungulates, in which earlier molar eruption might have evolved to acquire an efficient dentition more rapidly in a changing environment during the middle and late Paleogene of South America (Gomes Rodrigues et al. 2017).

We investigated tooth eruption patterns in Soay and other domestic sheep breeds in comparison to wild spe- cies in order to elucidate differences associated with the domestication process and island evolution. If Schultz's rule results from the domestication process, we would predict to find earlier molar eruption in relation to premolars in domestic sheep compared to wild sheep. If Soay sheep follow a similar trend as Myotragus, we would predict delayed molar eruption in Soay sheep compared to other domestic sheep in absolute and relative terms, and also according to Schultz's rule. Earlier studies pointed out that tooth eruption tends to be completed at an absolute older age in Soay sheep compared to other domestic sheep (Benzie and Gill 1974; Moran and O'Connor 1994; Jones 2002) (Table 1). However, this trend has remained relatively unexplored and hypotheses to explain this peculiar pattern have not been put forward. Our study provides new data on tooth eruption in known age sheep of different domestic breeds to complement and discuss the findings in an evolutionary perspective. 
Table 2 Life history traits of sheep. Comparisons of life history variables between wild and domestic sheep (Dom.) and wild and Soay sheep (Soay), respectively, are given in the bottom two rows

\begin{tabular}{|c|c|c|c|c|c|}
\hline Groups & Young per birth & $\begin{array}{l}\text { Gestation time } \\
\text { (d) }\end{array}$ & $\begin{array}{l}\text { Sexual } \\
\text { maturity (y) }\end{array}$ & $\begin{array}{l}\text { Longevity } \\
\text { (y) }\end{array}$ & Breeding \\
\hline \multicolumn{6}{|l|}{ Wild sheep } \\
\hline Ovis ammon ${ }^{\mathrm{a}}$ & $1-2^{\mathrm{b}, \mathrm{c}}$, up to 5 in captivity ${ }^{\mathrm{d}}$ & $\begin{array}{l}155-165^{\mathrm{b}} \\
150^{\mathrm{c}, \mathrm{d}}\end{array}$ & $1.5-5^{\mathrm{b}}$ & $13^{\mathrm{b}}$ & Seasonal $^{\mathrm{b}}$ \\
\hline Ovis arkal & $1-2^{\mathrm{d}, \mathrm{e}}$ & $150-160^{\mathrm{b}}$ & $1.5^{\mathrm{b}}$ & $11^{\mathrm{b}}$ & Seasonal $^{\mathrm{b}}$ \\
\hline Ovis vignei & $1-3^{\mathrm{b}, \mathrm{e}}$ & $\begin{array}{l}150-160^{\mathrm{b}} \\
180^{\mathrm{c}}, 150^{\mathrm{d}}\end{array}$ & $1.5^{\mathrm{b}}$ & $10^{\mathrm{b}}$ & Seasonal ${ }^{\mathrm{b}, \mathrm{f}}$ \\
\hline Ovis cycloceros & $1-2^{\mathrm{b}, \mathrm{e}}$ & $150-160^{\mathrm{b}}$ & $1.5^{\mathrm{b}}$ & $10^{\mathrm{b}}$ & Seasonal $^{\mathrm{b}}$ \\
\hline Ovis orientalis $^{\mathrm{g}}$ & $1-2^{\mathrm{b}}$ & $150-210^{\mathrm{b}}$ & $2-3^{b}$ & $18^{\mathrm{b}}$ & Seasonal $^{\mathrm{b}}$ \\
\hline \multicolumn{6}{|l|}{ Domestic sheep } \\
\hline Ovis aries musimon & $1-2^{b}$ & $\begin{array}{l}150-210^{\mathrm{b}, \mathrm{c}} \\
148-159^{\mathrm{d}}\end{array}$ & $1-3.5^{\mathrm{b}}$ & $14^{\mathrm{b}}$ & Seasonal / non-seasonal in captivity \\
\hline Ovis aries, Soay sheep & $1-2^{\mathrm{h}}$ & $142-155^{\mathrm{i}, \mathrm{j}}$ & $0.6^{\mathrm{h}, \mathrm{k}}$ & $10-16^{\mathrm{h}, 1}$ & Seasonal ${ }^{\mathrm{h}}$ \\
\hline $\begin{array}{l}\text { Ovis aries, other than } \\
\text { Soay }\end{array}$ & $\begin{array}{r}1-3^{\mathrm{c}}, 4 \text { not rare }{ }^{\mathrm{c}} \& \text { up to } 6 \\
\text { possible in some breeds }\end{array}$ & $144-152^{\mathrm{c}}$ & $0.6-1^{\mathrm{n}}$ & $12^{\mathrm{b}}$ & Seasonal / non-seasonal ${ }^{\circ}$ \\
\hline \multicolumn{6}{|l|}{ Comparisons } \\
\hline $\begin{array}{l}\text { Domestic vs. wild } \\
\text { sheep }\end{array}$ & Dom. > Wild & Dom. $\leq$ Wild & Dom. $<$ Wild & Dom. $=$ Wild & Dom. more non-seasonal than Wild \\
\hline $\begin{array}{l}\text { Soay vs. other domestic } \\
\text { \& wild sheep }\end{array}$ & $\begin{array}{l}\text { Soay }<\text { Dom. } \\
\text { Soay }=\text { Wild }\end{array}$ & $\begin{array}{l}\text { Soay }=\text { Dom. } \\
\text { Soay } \leq \text { Wild }\end{array}$ & $\begin{array}{l}\text { Soay }=\text { Dom. } \\
\text { Soay }<\text { Wild }\end{array}$ & $\begin{array}{l}\text { Soay }=\text { Dom } \\
\text { Soay }=\text { Wild }\end{array}$ & $\begin{array}{l}\text { Soay more seasonal than Dom., } \\
\text { seasonality similar to Wild }\end{array}$ \\
\hline
\end{tabular}

Information on sexual maturity and life span are summarized for males and females. Wild sheep are ordered from top to bottom according to species average adult shoulder height. $\mathrm{d}=$ days, $\mathrm{m}=$ months, $\mathrm{y}=$ years

a including Ovis ammon polii

b Castelló (2016)

c Asdell (1964)

d Schaller (1977)

e Twins and triplets are usually born in high forage production habitats and in older ewes

${ }^{\mathrm{f}}$ captive $O$. vignei in the London Zoo exhibit a seasonal breeding pattern, like in the wild, but captive $O$. a. musimon in the London Zoo have been observed to breed year round, i.e., non-seasonally (Asdell 1964)

g synonymous to Ovis gmelini gmelini according to Castelló (2016)

${ }^{\text {h }}$ Clutton-Brock et al. (2004b)

${ }^{\mathrm{i}}$ Doney et al. (1974)

j Jewell and Grubb (1974)

${ }^{\mathrm{k}}$ Stevenson et al. (2004)

${ }^{1}$ Grubb (1974)

${ }^{\mathrm{m}}$ Freetly and Leymaster (2004)

${ }^{\mathrm{n}}$ Fraser (1968)

${ }^{\circ}$ Rosa and Bryant (2003)

\section{Materials and Methods}

\section{Specimens}

Mandibular teeth of 156 sheep that died at different absolute individual ages were examined for this study. Our sample comprises three main types of sheep (Table 3): domestic, feral domestic, and wild. Domestic sheep (O. aries) are those that are currently used as livestock, kept and bred by humans for wool, fur, meat, and/or milk, and are represented by Karakul and Swiss sheep in this study. Feral domestic sheep represent livestock that is no longer under human control and roams and breeds freely in the wild, and is represented by Soay sheep (O. aries) and European mouflon (O. a. musimon) in this study. Wild sheep are the non-domestic relatives of the domestic sheep, and are represented by urial/arkar $(O$. vignei, $O$. cycloceros, $O$. arkal), red sheep (O. orientalis), and argali (O. ammon) in this study. Soay sheep were collected as part of a long term study on St. Kilda, Scotland (Jewell et al. 1974; Clutton-Brock and Pemberton 2004b). Two additional domestic sheep breeds $(O$. aries) with a small number of available specimens served as a comparison for the age at full third 
Table 3 Number of specimens (lower jaws) examined in this study (n). Species names are according to Wilson and Reeder (2005) and Gentry et al. (2004)

\begin{tabular}{|c|c|c|}
\hline Groups & Species & $\mathrm{n}$ \\
\hline \multicolumn{3}{|l|}{ Feral domestic sheep } \\
\hline Soay sheep & Ovis aries & 24 \\
\hline European mouflon & Ovis aries musimon & 32 \\
\hline \multicolumn{3}{|l|}{ Domestic sheep } \\
\hline Karakul & Ovis aries & 33 \\
\hline Swiss sheep ${ }^{a}$ & Ovis aries & 35 \\
\hline \multicolumn{3}{|l|}{ Wild sheep } \\
\hline Urial/arkar (vignei-division) & Ovis arkal, Ovis cycloceros, Ovis vignei & 15 \\
\hline Red sheep (orientalis-division) & Ovis orientalis & 5 \\
\hline Argali & Ovis ammon & 12 \\
\hline
\end{tabular}

molar eruption: meat merino $(n=4)$ and Rhön sheep $(n=6)$. To corroborate our age estimates (see below), we used an additional 13 Soay sheep individuals with known birth and death dates for which only skulls (no jaws) were available. The selection of domestic sheep breeds in this study was based on the availability of a sufficient number of young and knownage specimens. Data were sampled in the following museum collections: Museum für Haustierkunde 'Julius Kühn,' Martin-Luther-Universität Halle-Wittenberg, Germany (HTK), The Natural History Museum, London, United Kingdom (BMNH), Naturhistorisches Museum Basel, Switzerland (NMB), National Museum of Scotland Zoological Collections Centre, Edinburgh, United Kingdom (NMSZ), Naturhistorisches Museum Wien, Austria (NMW), Museum für Naturkunde Berlin, Germany (ZMB_Mam), University Museum of Zoology Cambridge, United Kingdom (UMZC), and Zoologische Staatssammlung München, Germany (ZSM). All specimens are part of institutional collections and no live animals were used. Some of the wild sheep have been bred in captivity (Online Resource 2).

There is currently no consensus about the systematics of wild sheep (Hiendleder et al. 2002) and in this work we generally follow Wilson and Reeder (2005). However, for the wild populations we used the scientific names of the wild species, as suggested by Gentry et al. (2004), although some of them have previously been classified as subspecies of $O$. aries (Wilson and Reeder 2005). Classification of museum specimens was sometimes problematic due to taxonomic ambiguity; we classified specimens according to the species affiliation as given on the collection label and, if applicable, the geographic locality where the specimens have been sampled, in combination with known distribution areas of the wild sheep species (Harris and Reading 2008; Valdez 2008). It is not yet clear which Eurasian wild sheep population(s) was (or were) the ancestor of domesticated sheep but it has been found that there were probably multiple domestication events and that the candidate ancestors are probably different populations of O. orientalis (see Pedrosa et al. (2005) for a review). Due to this uncertainty we sampled all previously suggested candidate species (Table 3): O. vignei, O. cycloceros, O. arkal, $O$. orientalis, and $O$. ammon.

We sampled individuals of both sexes and excluded individuals showing pathological conditions of the teeth, mandible, or rostrum affecting the teeth. Only specimens with a complete set of cheek teeth in the lower jaw were used for the analyses (see below). Care was taken to not consider neutered specimens, as castration might influence the timing of tooth eruption (Clutton-Brock et al. 1990, but see Davis 2000 and Worley et al. 2016) and skeletal growth (Popkin et al. 2012). However, castration may not have been consistently reported in collection databases and therefore cannot be entirely excluded.

\section{Analysis of Tooth Eruption}

Tooth eruption was coded using three stages: 1, not erupted; the tooth is not yet erupted above the alveolar level, but might be visible in the crypt. 2, erupting; the tooth has started to erupt and is above the alveolar level, but has not yet reached the occlusal plane. 3, fully erupted; the tooth is fully erupted into occlusion. The last stage was determined according to first signs of wear and the attainment of a position of the crown in one line with other fully erupted teeth (in the occlusal plane). Intermediate eruption stages 1.5 and 2.5 were used in cases of ambiguity or asymmetry between the left and the right side of the jaws. For example, if it was difficult to determine whether the first cusp of a tooth was already above the alveolar level, the tooth locus was allocated to stage 1.5; if a tooth 
has started to erupt on the left side of the jaw but not the right, the tooth locus was also identified as 1.5; if it was impossible to determine if a tooth has just reached the occlusal plane or if there was still a fraction of a millimeter before full eruption, the tooth locus was allocated to stage 2.5. Teeth of the lower jaw are denoted in lower case and teeth of the upper jaw in upper case; $\mathrm{P} / \mathrm{p}$ is for premolars; $\mathrm{M} / \mathrm{m}$ is for molars; numerals represent the respective tooth locus. For example, p2 is the second lower premolar and M1 is the first upper molar. The dental formula in Ovis is $0 \mathrm{I}, 0 \mathrm{C}, 3 \mathrm{P}, 3 \mathrm{M} / 3 \mathrm{i}, 1 \mathrm{c}, 3 \mathrm{p}, 3 \mathrm{~m}$, where the premolars are usually denoted as $\mathrm{P} 2 / \mathrm{p} 2, \mathrm{P} 3 / \mathrm{p} 3$, and $\mathrm{P} 4 / \mathrm{p} 4$. Only cheek teeth (premolars and molars) were considered for the analyses (see below) because incisors and canines are often lost post-mortem in sheep (Jones 2002) and therefore often missing in museum specimens. However, beginning incisor eruption could still be determined in Soay sheep. We further considered only the teeth of the lower jaw for the analyses (see below) because the skull length was often unavailable due to broken premaxillae in many specimens.

To quantify the relative dental maturity of every specimen, an eruption score was calculated as the sum of eruption stages of all lower cheek teeth. For example: a specimen with premolars and $\mathrm{m} 3$ in their crypts (stage 1 ), but $\mathrm{m} 1$ and $\mathrm{m} 2$ fully erupted (stage 3$)$ would receive a score of $10\left(1_{\mathrm{p} 2}+1_{\mathrm{p} 3}+\right.$ $1_{\mathrm{p} 4}+3_{\mathrm{m} 1}+3_{\mathrm{m} 2}+1_{\mathrm{m} 3}=10$ ). A dentally mature individual would receive a score of 18 ( 3 for all 6 cheek teeth). We assumed that specimens with many erupting and fully erupted teeth (stage 2 and 3) are older than specimens with fewer erupting and erupted teeth (an assumption validated by our specimens of known age). Specimens with only few erupted teeth would have a smaller eruption score, whereas specimens with many erupting and erupted teeth would have a larger eruption score. Our focus on one taxon (Ovis) with a consistent dental formula enabled us to avoid having to scale eruption scores (e.g., observed/maximum), necessitated in other studies that examine eruption across species with distinct dental formulae (e.g., Asher and Lehmann 2008). To compare relative dental maturity among our Ovis specimens, we took the ratio of observed:maximum eruption score in percent (e.g., $10: 18$ or $56 \%$ for the above example with fully erupted $\mathrm{m} 1-2$ ). Non-parametric Mann-Whitney-U tests in Past version 3.17 (Hammer et al. 2001) were used to compare eruption scores in relation to absolute age in Soay sheep vs. the other sheep breeds (Karakul and Swiss sheep).

For the domestic sheep (O. aries: Soay sheep, Karakul, and Swiss sheep, but not for the European mouflon, see below), only specimens with known age at death (known date of birth and known date of death, as documented in the collection databases) were considered here. Specimens were ordered according to individual absolute age, which enabled determination of the tooth eruption sequence for each group (Soay sheep, Karakul, and Swiss sheep). For ten Soay specimens, only the year of birth (but not day or month) was known; for one Soay specimen, only the month and year of birth (but not the day) was known. However, Soay sheep in the wild have a restricted birth season. Although birth dates may range from 25 March to 12 August, median dates of birth observed over 15 years are between 15 and 25 April (Clutton-Brock et al. 2004b). The overall median birth date is therefore 21 April, and so this date was used for the specimens with unknown birth days and months. The day of death was unknown for five animals, but these still had a known month of death, and we assumed death took place on the first day. An extended sample of Soay sheep was used to evaluate this age estimation. For a given eruption score, the ages of known age specimens (day and month of birth and death known) were compared to the ages of specimens with estimated dates (Online Resource 1). Maxillary cheek teeth were used for this analysis due to greater abundance of precisely known ages among specimens that lacked jaws. In wild sheep (O. vignei, O. cycloceros, $O$. arkal, O. orientalis, O. ammon) and feral domestic European mouflon (O. a. musimon), the absolute age at death was not known for most specimens and the sequence of eruption was determined by ordering the specimens according to the eruption score.

Mandibular length was measured as the distance between the most posterior point of the mandibular condyle and the most anterior point of the mandibular symphysis, measured at the level of the alveoli of the central incisors (Asher and Lehmann 2008). It was not possible to measure mandibular length in all specimens and groups. For example, an adequate number of measurements in wild sheep was only possible for urial/arkar. To quantify ontogenetic size variation, we calculated the percent median adult mandibular length in every specimen sufficiently complete to measure. The median adult mandibular length is here defined as the median mandibular length of all specimens dentally or absolutely older than, or at a similar (dental) age as, the youngest specimen with a complete set of fully erupted cheek teeth (i.e., all premolars and molars in stage 3 ), with no older specimens exhibiting noncomplete eruption of cheek teeth (see also Asher and Lehmann 2008; Asher and Olbricht 2009). In the domestic sheep this coincides with an absolute age of about three years and above. All data generated or analyzed during this study are included in this published article and its supplementary information file (Online Resource 2).

\section{Results}

\section{Tooth Eruption in Wild Vs. Domestic Sheep}

Although there is some variation in tooth eruption as it relates to the absolute age among individuals, cheek teeth eruption sequences are similar in the wild and domestic sheep (Fig. 1, Table 4, Online Resource 2). In all examined groups, $\mathrm{m} 1$ is the 
first permanent cheek tooth to start erupting and it is fully erupted before $\mathrm{m} 2$ starts to erupt. The $\mathrm{m} 2$ is fully erupted before the premolars start erupting and before $\mathrm{m} 3$ starts erupting. The eruption sequence among premolars appears to be variable and also closely timed, so that a consistent order among premolars cannot be determined. One reason for this might be that in some individuals, deciduous cheek teeth conceal the underlying permanent premolars in their early phases of eruption above the alveolus. The $\mathrm{m} 3$ and M3 take more time to fully erupt compared to the premolars and eruption of $\mathrm{m} 3$ and $\mathrm{M} 3$ is still underway while all premolars are already fully erupted and in wear. The most posterior cusp of $\mathrm{m} 3$ (hypoconulid) takes a particularly long time until it becomes fully functional and in wear. Cheek teeth initiate their eruption (transition of loci from stage 1 to 2) as follows: m1-m2-p2/p3/ $\mathrm{p} 4 / \mathrm{m} 3$. (Hyphens denote a resolved sequence, slashes simultaneous eruption or ambiguity.) The sequence of complete tooth eruption into occlusion (transition of loci from stage 2 to 3 ) is $\mathrm{m} 1-\mathrm{m} 2-\mathrm{p} 2 / \mathrm{p} 3 / \mathrm{p} 4-\mathrm{m} 3$. This sequence also applies to the upper jaw, although the teeth from the upper and the lower jaws do not erupt simultaneously (Online Resource 2). The eruption sequences of Ovis and Myotragus mainly differ in two ways. First, $\mathrm{m} 3$ in Myotragus does not start erupting until p4 is fully erupted and in occlusion (Bover and Alcover 1999; Jordana and Köhler 2011; Jordana et al. 2013) while in Ovis, $\mathrm{p} 4$ and $\mathrm{m} 3$ begin eruption around the same time (Fig. 1). Second, i1 starts to erupt before $\mathrm{m} 2$ in derived Myotragus (Jordana et al. 2013) but after $\mathrm{m} 2$ is completely erupted in Ovis. One of the few Soay sheep in our sample with preserved incisors shows completely erupted $\mathrm{m} 1$ and $\mathrm{m} 2$ while the permanent il just starts erupting above the alveolar plane (Fig. 2).

\section{Tooth Eruption in Soay Vs. Other Domestic Sheep}

While the timing of cheek tooth eruption in Soay sheep lies in the range of the other domestic breeds, Soay sheep tend to erupt their teeth late within that range (Figs. 3 and 4, Table 4). For example, Soay sheep exhibit an eruption score of 10 (which indicates $\mathrm{m} 1$ and $\mathrm{m} 2$ are the only fully erupted, permanent cheek teeth) at on average 1.86 years $(n=2)$; the other breeds show the same score between 1.10-1.61 years $(n=9$, median $=1.48$ years; Fig. 3 ), a difference which is statistically significant (Mann-Whitney $U=0, p=0.045$ ). At about two years (1.82-2.05 years, an age range for which there is data for Soay sheep, Swiss sheep, and Karakul), Soay sheep exhibit eruption scores of 10-13 $(n=7$, median $=11)$, whereas Karakul and Swiss sheep have eruption scores of $11-16.5 \quad(n=6$, median $=13.5$; Fig. 3), a difference which is statistically significant as well (Mann-Whitney $U=6.5, \mathrm{p}=0.04$ ). Moreover, Soay
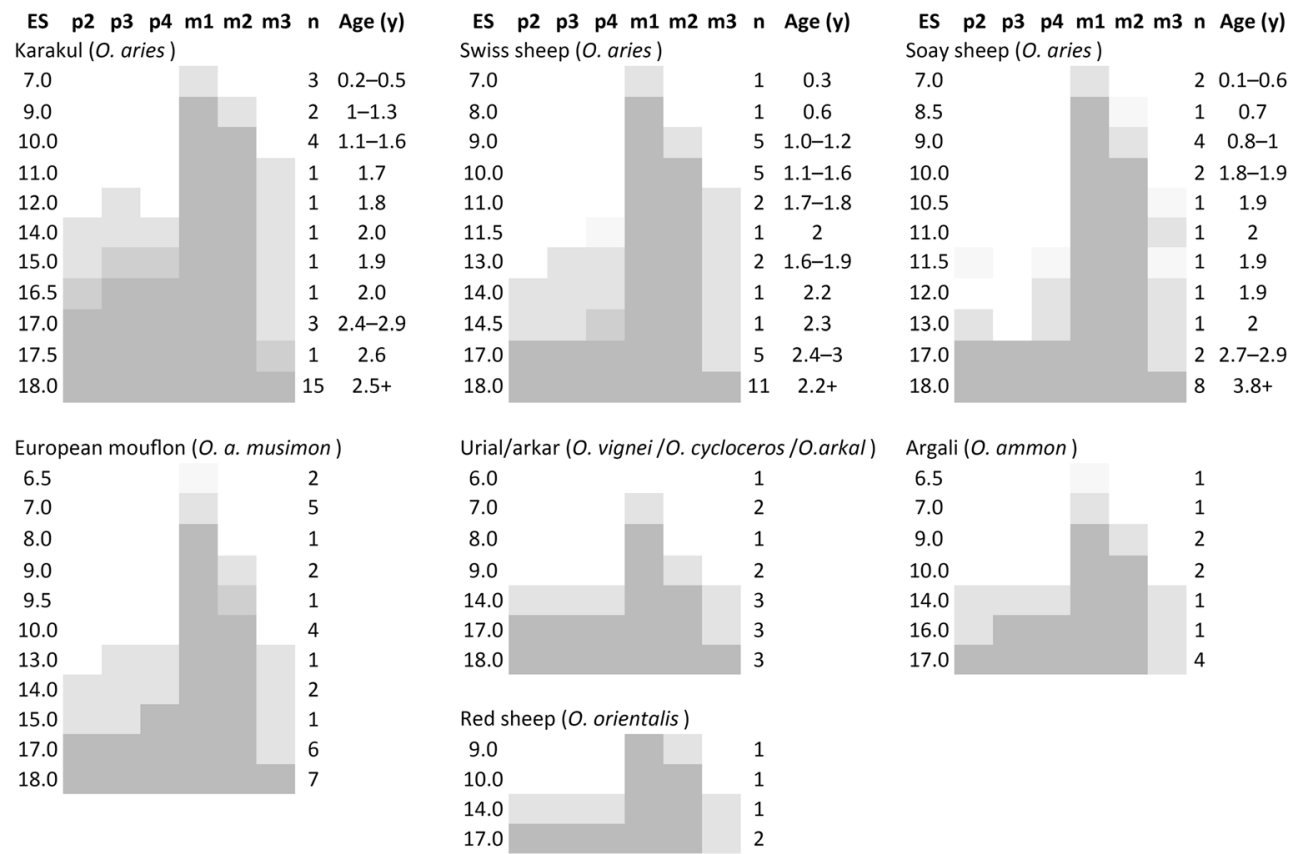

Fig. 1 Heat maps of tooth eruption in Ovis. Rows indicate the different eruption scores (ES) that could be sampled in every group, along with the respective eruption stage for every lower cheek tooth (p2 - p4, m1 - p3) as well as the number of specimens exhibiting the respective eruption score (n) and their age in years (Age (y)), where applicable. Shading of eruption scores is as follows: white $=$ stage 1 (not erupted), light grey $=$ stage 2 (part erupted), dark grey $=$ stage 3 (fully erupted and in occlusion).

Intermediate shadings denote intermediate eruption stages, i.e., 1.5 and 2.5. All groups have the same eruption sequence (dashes and slashes indicate sequence and ambiguity, respectively): $\mathrm{m} 1-\mathrm{m} 2-\mathrm{p} 2 / \mathrm{p} 3 / \mathrm{p} 4 / \mathrm{m} 3$ for beginning eruption and $\mathrm{m} 1-\mathrm{m} 2-\mathrm{p} 2 / \mathrm{p} 3 / \mathrm{p} 4-\mathrm{m} 3$ for complete eruption. Note that differences in the sample size (Table 3) influences the resolution of the sequences 
Table 4 Age (in years) at beginning and complete eruption of lower premolars ( $\mathrm{p}$ ) and molars (m1-3) in Ovis and Myotragus balearicus

\begin{tabular}{lllllll}
\hline Group & Eruption & $\mathrm{p}$ & $\mathrm{m} 1$ & $\mathrm{~m} 2$ & $\mathrm{~m} 3$ & Reference \\
\hline Soay sheep & Beginning & 1.86 & $<0.6$ & 0.7 & 1.9 & This study \\
& Complete & $1.99-2.68$ & $0.6-0.7$ & $0.9-1.8$ & $\mathrm{UJ}$ : 2.9-3.9 & \\
Karakul & Beginning & $1.7-1.8$ & 0.2 & $0.5-1.0$ & 1.7 & This study \\
& Complete & 2.0 & 0.5 & $1.1-1.3$ & $2.5-2.9$ & \\
Swiss sheep & Beginning & $1.6-1.8$ & $\sim 0.3$ & $0.6-1.0$ & $1.6-1.7$ & This study \\
& Complete & $2.2-2.3$ & $0.3-0.6$ & $1.1-1.2$ & $2.2-3.0$ & \\
Rhön Sheep & Beginning & 1.7 & na & na & na & This study \\
& Complete & na & na & na & $<2.9$ & \\
Meat merino & Beginning & na & na & 0.7 & na & This study \\
Myotragus balearicus & Complete & na & na & na & $<3.1$ & \\
Domestic Ovis aries & Complete & na & 1 & 2.7 & 5.8 & (Jordana and Köhler 2011; Marín-Moratalla et al. 2011) \\
\hline
\end{tabular}

Age information is given according to known or estimated individual ages of specimens in which the respective molars have just started to erupt ('beginning': first cusps above the alveolus, stage 2) and in which the tooth is fully erupted into occlusion ('complete', stage 3). If such specimens were not applicable, age ranges are given. For beginning eruption, age ranges represent the age of the oldest specimen with a not yet erupting tooth (stage 1) and the youngest specimen with an erupting tooth (stage 2). Similarly, age ranges for complete eruption represent the age of the oldest specimen with a not yet fully erupted tooth (stage 2 ) and the youngest specimen with a fully erupted tooth (stage 3 ). Na = not applicable. The upper jaw (UJ) and the lower jaw (LJ) were only considered separately if the timing of eruption was markedly different

sheep tend to erupt their third molars considerably later, i.e., between three and five years, compared to the other domestic sheep breeds, which have a completely erupted m3 and M3 by three years (Fig. 4a, b, Table 4). However, Soay sheep do not quite reach the old age of Myotragus at the eruption of these teeth, which may exceed five years without a fully erupted $\mathrm{m} 3$ (Table 4, Jordana and Köhler 2011).

\section{Size, Tooth Eruption, and Age}

Lower jaws of adult Karakul and Swiss sheep are of approximately similar size, while those of Soay sheep are smaller (Fig. 5). The youngest, non-dentally mature Soay sheep to reach the adult mandibular length range of its breed is 1.95 years old, while the youngest Karakul and the youngest

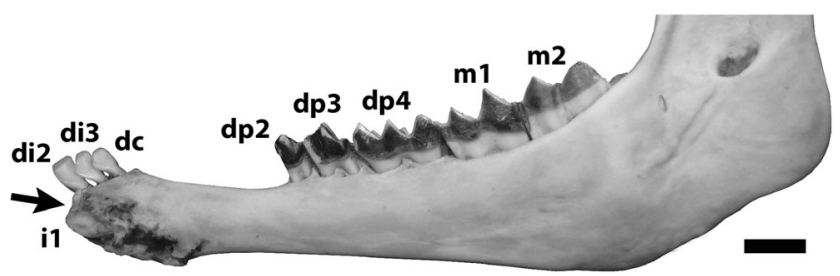

Fig. 2 First lower incisor eruption in Soay sheep. The Soay sheep specimen NMSZ YW186 exhibits fully erupted $\mathrm{m} 1$ and $\mathrm{m} 2$ while the permanent i1 (arrow) is just about to start eruption above the alveolar plane. The prefix ' $\mathrm{d}$ ' is used to denote deciduous teeth. This specimen reveals an eruption pattern in Soay sheep that is typical for extant sheep and different from derived members of the Myotragus-lineage, in which i1 erupts after $\mathrm{m} 1$ and long before $\mathrm{m} 2$ (Jordana et al. 2013). Scale bar equals $1 \mathrm{~cm}$
Swiss sheep are 1.1 and 1.3 years old, respectively (Fig. 5). Lower jaws grow proportionally with tooth eruption progress in all Ovis investigated here. That is, most of the tooth eruption occurs during jaw growth and $95 \%$ of median adult jaw size is only attained when $50-60 \%$ of the maximum possible eruption score is reached (approximately corresponding with the full eruption of $\mathrm{m} 2$; Fig. 6a). This relation between tooth eruption and jaw growth is similar in both wild and domestic sheep. Figure 6 further shows the anteroposterior length of $\mathrm{m} 3$ and M3 in a Soay sheep specimen with all permanent cheek teeth fully erupted (NMSZ YB511, Fig. 6b-c) and the corresponding space this tooth would occupy in a younger specimen in which $\mathrm{m} 3$ and M3 have not yet started to erupt (NMSZ AY182, Fig. 6d-e).

\section{Discussion}

In this study we examined cheek teeth eruption in wild sheep (non-domestic, wild relatives of the domestic sheep), domestic sheep (livestock), and feral domestic sheep (livestock that roams and breeds freely in the wild without human control) of different breeds (Table 3 ) to investigate potential changes related to the domestication process and also to specific habitats, in this case an island environment. Concerning the effect of domestication on tooth eruption, we found no changes of the sequence of tooth eruption between domestic and wild sheep, no matter the species or breed (Fig. 1). Therefore, our data are not consistent with Schultz's rule as applied to 


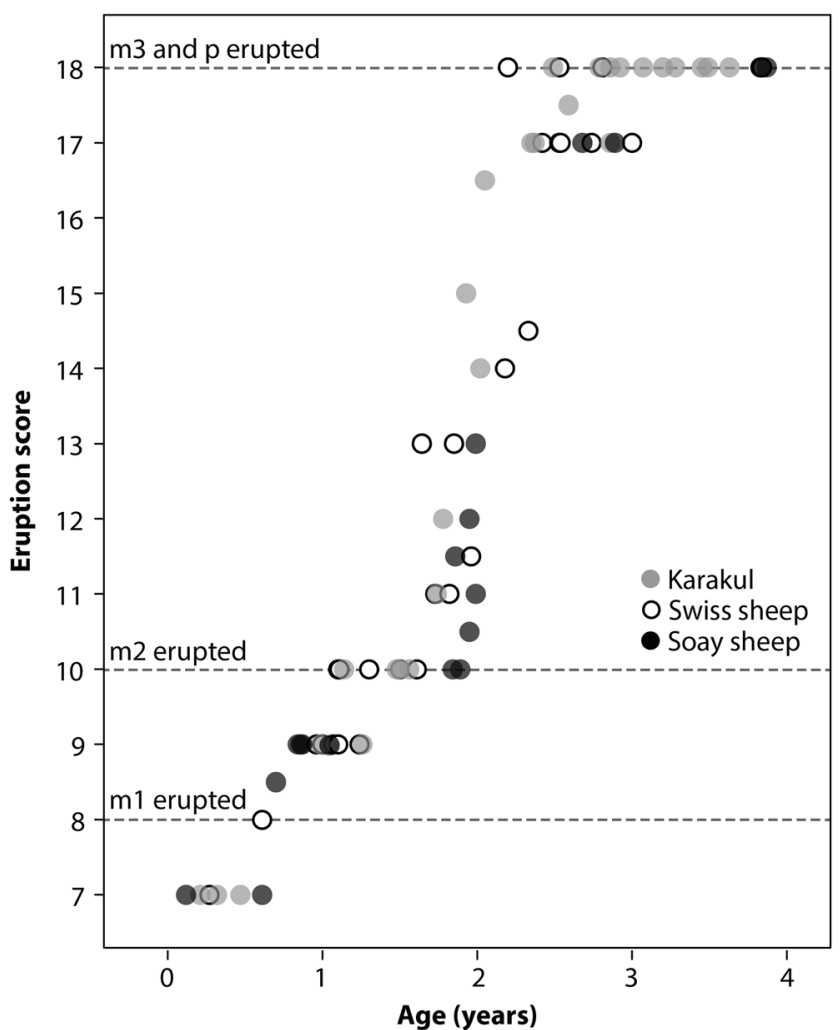

Fig. 3 Eruption score in relation to absolute individual age in Ovis aries. Different shadings of data points denote the different groups of sheep. The eruption score in which the first, second and third molars (m1-3) and the premolars (p) are fully erupted (stage 3 ) are indicated with dashed lines. Note that Soay sheep tend to be older at a given eruption score compared to the other breeds

eruption sequence, despite marked changes of life history in sheep due to domestication (Table 2). Concerning potential effects of the island environment on tooth eruption, we found that Soay sheep from the St. Kilda archipelago tend to erupt

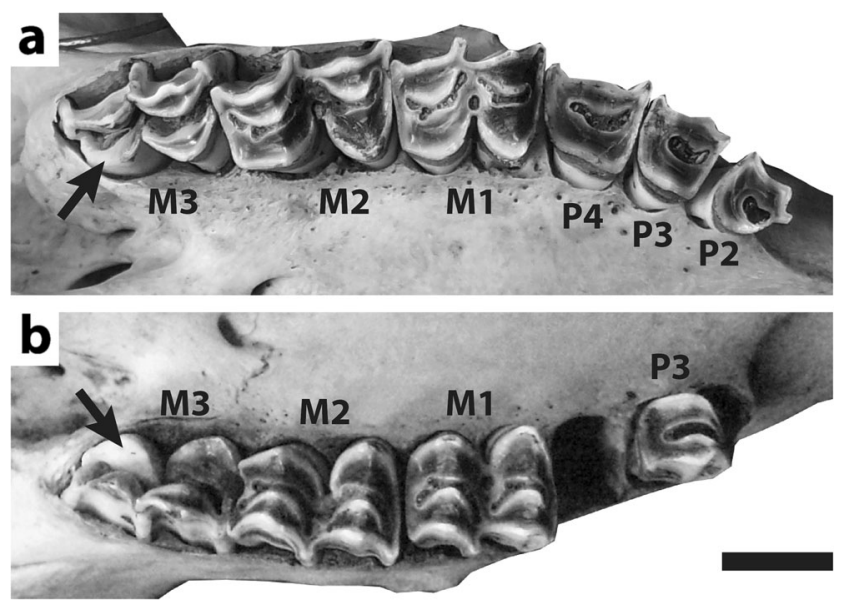

Fig. 4 Late cheek tooth eruption in Soay sheep. The upper tooth rows of two Soay sheep specimens aged 3.84 years (a, NMSZ YB155, mirrored) and 3.87 years (b, NMSZ YB511, mirrored) show that the posterior cusps of M3 are still not yet fully erupted and not in wear (arrows). Scale bar equals $1 \mathrm{~cm}$

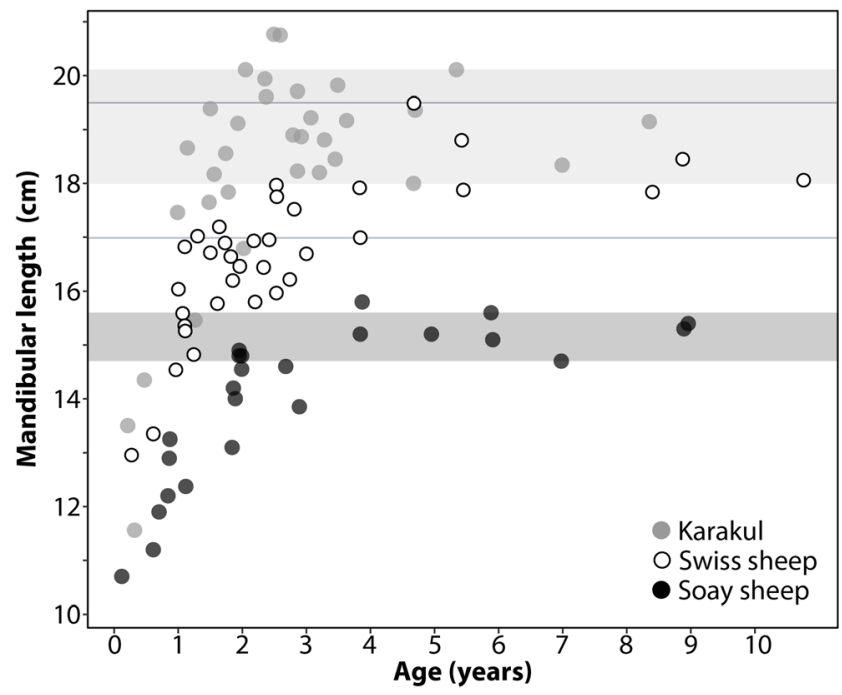

Fig. 5 Mandibular length in relation to absolute individual age in Ovis aries. Different shadings of data points denote the different groups of sheep. Mandibular length was measured as the distance between the most posterior point of the mandibular condyle and the most anterior point of the mandibular symphysis, measured at the level of the alveoli of the central incisors (Asher and Lehmann 2008). Shaded boxes represent the range of jaw sizes in dentally mature specimens, i.e., jaw size range of all specimens older than or at a similar age as the youngest specimen with a complete set of fully erupted cheek teeth (all premolars and molars in stage 3 ), with no older specimens exhibiting non-complete eruption of cheek teeth in that breed. Note that Soay sheep tend to have a smaller jaw at full growth, and yet attain adult size at a slightly older age compared to the other breeds

their cheek teeth later than the other domestic sheep breeds, especially the upper and lower third molars (Fig. 4, Table 4). This late eruption in Soay sheep corresponds to the pattern found in the island caprine Myotragus (Jordana and Köhler 2011) and to delayed molar eruption in slowly growing mammals, according to Schultz's rule (Smith 2000).

\section{Tooth Eruption and Domestication}

Life history traits of wild sheep, and changes resulting from domestication, are given in Table 2. Two young per birth (twinning) are common in at least some wild sheep species, e.g., O. vignei, O. ammon (Valdez 1976; Schaller 1977). Captive wild sheep (O. ammon polli) are known to have litters of up to five young per birth (Schaller 1977). However, at least some breeds of domestic sheep tend to have larger litters than wild Eurasian sheep (Table 2). Further, in domestic sheep, twinning is frequently observed in females in their second year of life, e.g., in Soay sheep (Clutton-Brock et al. 2004b), or even in the first year of life in some highly prolific breeds, e.g., Finnish landrace and Romanov (Dýrmundsson 1981). In contrast, wild sheep $(O$. laristanica, $O$. arkal) do not usually give birth to twins until the female is in her third year (Valdez 1976). Gestation times reported for wild and domestic sheep have overlapping ranges, but are slightly shorter in the 
a
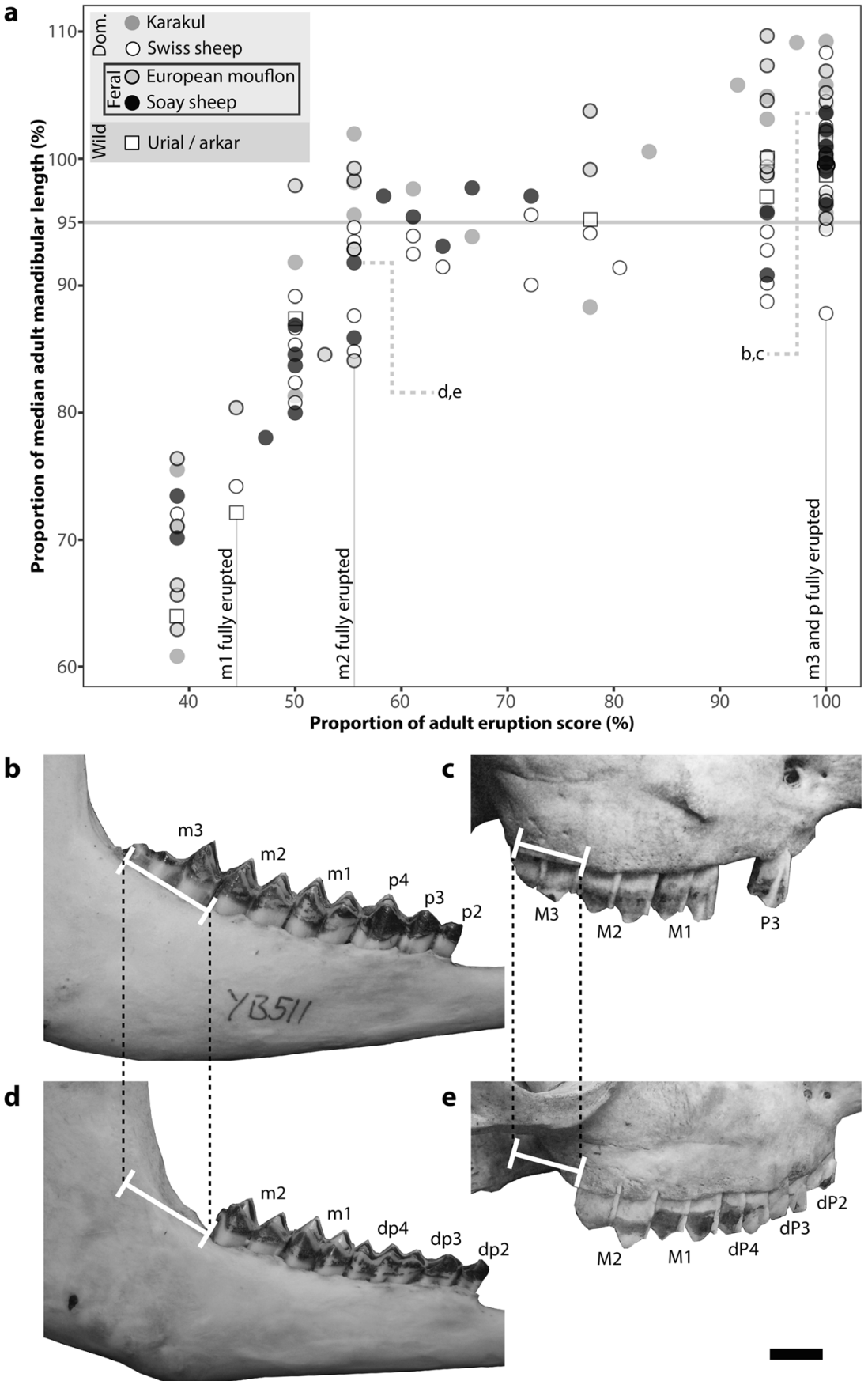

Fig. 6 Proportion of median adult mandibular length in relation to the proportion of adult eruption score in Ovis (a). The color code indicates the different groups of wild, domestic (Dom.), and feral domestic sheep according to Table 3 . The Y-axis shows the percentage of the median adult mandibular length for a given specimen (Asher and Lehmann 2008; Asher and Olbricht 2009). Adult mandibular length is here defined as the size range of all specimens older than or at a similar age as the youngest specimen with a complete set of fully erupted cheek teeth (all premolars and molars in stage 3 ), with no older specimens exhibiting noncomplete eruption of cheek teeth in that group. $95 \%$ of adult size is indicated with a horizontal grey line. The $\mathrm{X}$-axis shows the percentage of fully erupted cheek teeth. The percentages where the first, second, and third molars (m1-3) and the premolars (p), respectively, are fully erupted (stage 3) are indicated with vertical grey lines. Dashed lines and letters reference to the specimens shown in the lower part of the figure $(\mathbf{b}-\mathbf{e})$. Upper and lower dentition of two Soay sheep specimens of different tooth developmental stages $(\mathbf{b}-\mathbf{e})$. The top jaw and mandible (NMSZ YB511, $\mathbf{b}-\mathbf{c})$ show all permanent cheek teeth fully erupted in a jaw at $103.6 \%$ of median adult length; the bottom jaw and mandible (NMSZ AY182, d - e) shows $\mathrm{m} 1$ and $\mathrm{m} 2$ fully erupted and $\mathrm{m} 3$ in its crypt in a jaw at $91.8 \%$ of median adult length. The dashed lines and white brackets represent the anteroposterior length of $\mathrm{m} 3$ and M3 in NMSZ YB511 (b, c) and the corresponding space this tooth would occupy in the younger specimen NMSZ AY182 (d, e). Scale bar equals $1 \mathrm{~cm}$ 
domestic sheep, including Soay (Table 2). While domestic sheep generally begin to breed in their first year (if sufficiently heavy; Fraser 1968), breeding in wild sheep does not usually begin until after the first year (Table 2; Valdez 1976). Longevity is hard to compare in wild and captive populations due to different mortality in human-mediated environments. Nonetheless, longevity is similar in wild and domestic sheep, including Soay (Table 2). In order to synchronize the birthdate of the offspring with favorable environmental conditions, wild sheep generally breed seasonally; i.e., the breeding season is restricted to a certain time of the year (Rosa and Bryant 2003). Domestic sheep species from high latitudes $\left(>35^{\circ}\right)$ generally breed seasonally as well (Rosa and Bryant 2003) but some domestic breeds, e.g., meat merino (Fraser 1968; Behrens et al. 1983), Wrzosówka (Asdell 1964), and Romanov (Hafez 1952) have the potential to breed non-seasonally, even in seasonal environments. Non-seasonal reproduction may therefore have a genetic component (Lincoln et al. 1990). These comparisons illustrate that domestic sheep have an overall greater number of young per litter, a shorter gestation time, an earlier first reproduction, and more frequent breeding opportunities due to a potential lack of seasonality compared to wild sheep (Table 2). This is consistent with an acceleration of reproductive life history in sheep due to domestication.

Our tooth eruption sequences are consistent with those found by other authors for wild (Zeder 2002) and domestic sheep (Silver 1963; Habermehl 1975, 1985; Moran and O'Connor 1994; Jones 2002). Despite the accelerated life history due to domestication (Table 2), domestic sheep (O.aries and $O$. a. musimon) have not changed their sequence of tooth eruption compared to wild sheep (O. vignei, O. cycloceros, O. arkal, O. orientalis, O. ammon), contra Schultz's rule (Fig. 1). This might be due to particularly strong phylogenetic and functional constraints on dental eruption patterns among artiodactyls generally (Monson and Hlusko 2016; Veitschegger and Sánchez-Villagra 2016). Such constraints could include dental wear. Permanent cheek teeth in Ovis are high-crowned (hypsodont), which is an adaptation to elongate the functional lifespan of the teeth in species that consume highly abrasive plant material (e.g., grasses that contain phytoliths and/or are covered with grit) (Ungar 2010). However, the deciduous cheek teeth are low crowned (brachydont) and highly abrasive diet might make necessary a relative early replacement of the premolars, relative to the molars, to prevent them from wearing out (Böhmer et al. 2016). In addition, most dental eruption occurs during jaw growth (Fig. 6a), a correlation that might imply a size constraint for molar eruption and thus limitation to early molar eruption, as these teeth have no room to fully erupt into functional occlusion before the body of the mandible has attained a sufficient length. This appears to be the case in the period between about 55 and $100 \%$ of the maximum possible eruption score, when many specimens have already reached around $95 \%$ of the adult jaw size (Fig. 6a). The body of the mandible around the posterior tooth row, near the ascending ramus, is not yet extensive enough to house the $\mathrm{m} 3$ at the time when $\mathrm{m} 2$ is fully erupted (Fig. 6b, d). Similar size constraints are evident in the upper jaw (Fig. 6c, e). This relation between tooth eruption and jaw growth is similar in wild and domestic form of Ovis (Fig. 6a) and would thus comprise a mechanical restriction on the timing of tooth eruption in both. Cheek teeth can fit in to what appears to be a small jaw due to imbrication and oblique orientation of the teeth upon eruption in lemurs (Godfrey et al. 2005). Further, molars may erupt on the ascending ramus and only later descend into their final position in some carnivorans, e.g., Ursus (Veitschegger et al. 2018). However, such patterns are not observed in Ovis. In contrast, size restrictions are absent in several afrotherians (e.g., tenrecids, macroscelidids, chrysochlorids; Asher and Lehmann 2008; Asher and Olbricht 2009) and dasypodid xenarthrans (Ciancio et al. 2012), where the jaw approaches adult size before even half of the permanent dentition is fully erupted. Another possible explanation for the lack of a Schultz's rule effect on dental eruption sequence in Ovis is the relatively short timespan since initial domestication. Sheep have been domesticated for about 12,000 years (Driscoll et al. 2009), whereas the divergence times of the species for which Schultz's rule has some support are much greater (e.g., primates as discussed by Smith 2000 and Asher et al. 2017).

\section{Timing of Tooth Eruption among Domestic Sheep Breeds}

Data on the absolute timing of the dental stages shown in Fig. 3 are still unknown in wild sheep (e.g., O. orientalis). However, our data enable comparisons between domestic (Swiss, Karakul) and feral-domestic (Soay) sheep. The absolute ages of beginning and complete cheek teeth eruption (Table 4) correspond with the ages reported in the literature (Habermehl 1975; Moran and O'Connor 1994; Davis 2000; Jones 2002; Jordana and Köhler 2011). In domestic sheep, the timing of tooth eruption may vary with breed affiliation and it has been found that improved, 'early maturing', i.e., comparatively fast growing breeds, tend to erupt their incisors and canine teeth at a younger age compared to non-improved, 'slow maturing' ones (see e.g., Adametz 1926; Habermehl 1975; but see Moran and O'Connor 1994). Domestic sheep breeds investigated here are variable in terms of improvement and performance (Behrens et al. 1983; Haring et al. 1984; Sambraus 2016; Egloff 2017). The Karakul sheep is a lean, hardy, and slow maturing fat-tailed sheep, adapted to steppes and semi-deserts. The Swiss sheep varieties are also rather slow maturing and adapted to harsh mountainous environments. The Rhön sheep is adapted to rough and wet climate 
but is rather fast growing and has a potential for non-seasonal (i.e., more frequent) breeding. The meat merino is a comparatively fast growing and non-seasonal breeding sheep that does not thrive under harsh environmental conditions and scarce nutrient supply, unlike the more locally adapted breeds described above. We found that, regardless of differences in breed-specific life-history traits, breeds fully erupt their third molars around three years of age at the latest (Table 4). Soay sheep differ from this pattern as the third molars erupt later into occlusion than in the other domestic sheep (Fig. 4, Table 4). This corresponds with previous findings on late incisor and canine eruption in Soay sheep (Benzie and Gill 1974; Jones 2002).

Further evidence for slower dental growth of Soay sheep compared to other domestic sheep breeds comes from studies on enamel formation. The average rate of ameloblast differentiation of the molars, i.e., the crown/enamel extension rate, averaged across cuspal and cervical enamel regions, is $150 \mu \mathrm{m} \mathrm{d}^{-1}$ in a mainland Catalonian $O$. aries and $80 \mu \mathrm{m}$ $\mathrm{d}^{-1}$ in Myotragus (Jordana and Köhler 2011). The average crown extension rate of $\mathrm{m} 1$ in Soay sheep has been found to be $111 \mu \mathrm{m} \mathrm{d}^{-1}$ (Kierdorf et al. 2013), thus lying in between the comparatively slow rate of Myotragus and the relatively fast rate of the Catalonian sheep (O'Meara et al. 2018). The differences of enamel extension rates among these caprines are comparable in magnitude to interordinal differences, as exemplified by Equus with an average enamel extension rate of $178.3 \mu \mathrm{m} \mathrm{d}^{-1}$ (Nacarino-Meneses et al. 2017). Although more data across additional species and breeds are needed to further substantiate this hypothesis, these data suggest genuinely slower dental growth in Soay sheep compared to other domestic sheep, but growth that is still faster than in Myotragus.

Absolutely late tooth eruption has also been suggested for the European mouflon (Habermehl 1975, 1985; Table 5), a feral domestic sheep of ancient domestic origin (CluttonBrock 1999). As Soay sheep presumably resemble these very first domestic sheep in Europe (Campbell 1974) and are genetically close to European mouflons (Hiendleder et al. 2002; Chessa et al. 2009), relatively late tooth eruption might be a shared ancestral characteristic of basal domestic sheep. The timing of tooth eruption might have been accelerated in the more derived domestic sheep breeds.

\begin{tabular}{llll}
\cline { 2 - 4 } $\begin{array}{l}\text { Table } 5 \text { Mean absolute } \\
\text { age (in years) of } \\
\text { beginning cheek tooth }\end{array}$ & Locus & O. aries & O. a. musimon \\
\cline { 2 - 4 } $\begin{array}{l}\text { eruption (piercing of the } \\
\text { gingiva) in modern }\end{array}$ & $\mathrm{p} 2$ & 2.0 & 2.1 \\
domestic sheep (Ovis & $\mathrm{p} 3$ & 2.0 & 2.1 \\
$\begin{array}{l}\text { aries) and the ancient } \\
\text { feral European mouflon }\end{array}$ & $\mathrm{p} 4$ & 2.0 & 2.1 \\
(Ovis aries musimon) as & $\mathrm{m} 1$ & 0.3 & 0.4 \\
given by Habermehl & $\mathrm{m} 3$ & 0.8 & 1.2 \\
(1975, 1985) & 1.5 & 2.8 \\
\hline
\end{tabular}

If delayed tooth eruption is a derived feature in Soay sheep, what might be the reasons? Differences in nutritional supply might not play a role because the pastures on St. Kilda have a similar nutritional content as other seasonal grasslands (Milner and Gwynne 1974). However, although the condition of skeletons and dentition of Soay sheep from St. Kilda has been reported to be generally good and there is only little evidence of malnutrition (Benzie and Gill 1974; CluttonBrock et al. 1990), starvation is the usual cause of death and such sheep often show severe body mass reduction and depletion of virtually all fat reserves (Gulland 1992). Occasional delayed eruption of permanent incisors and canines due to comparatively low nutritional status has been suggested for Soay sheep on St. Kilda (Boyd et al. 1964). This hypothesis has been supported by various studies that have found that improved nutrition may accelerate incisor and canine eruption in sheep (for a review see e.g., Worley et al. 2016). Although lower quality nutritional supply has so far not been found to significantly slow down molar growth in sheep (Worley et al. 2016), extreme malnutrition, leading to scarcely any weight gain, has been shown to delay growth and eruption of most permanent teeth in pigs (McCance et al. 1961). Besides environmentally induced delay of tooth eruption, there might also be a genetic component: Jones (2002) noted late tooth eruption in a Soay sheep population raised in captivity in the South Downs, England.

Compared to other domestic sheep breeds, Soay sheep are smaller and mandibular length appears to reach the adult size range slightly later in absolute terms (Fig. 5). This pattern might comprise a sampling artefact due to the smaller sample size in Soay sheep (Table 3) and the fact that most deaths on St. Kilda occur in late winter close to the lambing season; therefore, Soay sheep mostly live for a given number of whole years (Morton Boyd and Jewell 1974), restricting the resolution of eruption scores in-between whole years (Fig. 5). Furthermore, the estimated age in many of the Soay sheep might restrict the explanatory power here, although comparisons with known age Soay sheep showed that the estimated ages were similar for a given eruption score or even slightly underestimated (Online Resource 1). Despite this limitation, our findings indicate that Soay sheep probably do grow more slowly than other domestic sheep breeds. This finding is supported by the Soay sheep's relatively slow rate of body mass increase from birth to adulthood compared to other sheep breeds (Boyd et al. 1964). A delay of skeletal growth could be made up for later during ontogeny, as Soay sheep do not fuse growth plates later than other sheep breeds: epiphyseal fusion occurs around 3-3.5 years in all breeds for which there are data, including Soay sheep (Clutton-Brock et al. 1990). In terms of slow growth and tooth eruption, Soay sheep thus resemble Myotragus. Soay sheep and Myotragus both experienced density-dependent population growth on esource-limited, predator-free islands with frequent starvation-related 
bottlenecks (Milner and Gwynne 1974; Clutton-Brock et al. 2004a, b; Jordana and Köhler 2011). In Myotragus it has been suggested that this limited resource availability was the main selection pressure leading to the evolution of small body size and slow growth and life history (Palkovacs 2003; Köhler and Moyà-Sola 2009; Jordana and Köhler 2011). Therefore, a similar evolutionary process as in Myotragus might also be responsible for the observed trend toward a slowdown of skeletal and dental growth in Soay sheep. However, apart from slower mandibular growth and tooth eruption, life history variables (e.g., onset of reproduction) are not as slow in Soay sheep (Table 1) and therefore do not support the presence of similar selection pressures in Soay sheep and Myotragus.

This is supported by peculiar tooth eruption patterns in derived members of the Myotragus evolutionary lineage, which probably represent adaptations to the island environment in accordance with Schultz's rule (Jordana et al. 2013), but that are not present in Soay sheep. First, in Myotragus, m3 does not start erupting until $\mathrm{p} 4$ is fully erupted and in occlusion (Bover and Alcover 1999; Jordana and Köhler 2011; Jordana et al. 2013). In our sample of Ovis, including Soay sheep, $\mathrm{p} 4$ and $\mathrm{m} 3$ begin eruption around the same age (Fig. 1). Second, in derived species of the Myotragus lineage, the single permanent incisor (i1) starts erupting after $\mathrm{m} 1$ is fully erupted but before formation of $\mathrm{m} 2$ begins (Jordana et al. 2013). This is in contrast to other caprines, including Soay sheep (Fig. 2), in which i1 only starts erupting after $m 2$ is already erupted (Jordana et al. 2013). Also here, temporal differences might play a role. While Myotragus evolved on the Balaeric islands for more than 5 million years, and changes of tooth eruption sequence can be traced over a period of about 2.5 million years (Jordana et al. 2013), the persistence time of Soay sheep on St. Kilda is only about 4000 years at most (Table 1). This much shorter timespan in Soay sheep was probably not sufficient for fundamental changes in tooth eruption sequence to occur. In addition, an ongoing trend of declining body size and growth rate in Soay sheep on St. Kilda, resembling the observed evolutionary trend in Myotragus, has been found to be the result of phenotypic plasticity in response to environmental changes rather than being an evolutionary adaptive response to resource limitation on an island (Ozgul et al. 2009).

\section{Conclusions}

Domestication and its fundamental influence on the biology of sheep, notably life history, do not change the sequence of dental eruption in domestic sheep compared to their wild relatives. On the other hand, there are differences in the absolute timing of tooth eruption in the ancient island Soay sheep population compared to more improved mainland sheep breeds.
There is a slightly later eruption of the third molar in Soay sheep and Myotragus compared to their non-island relatives but we hypothesize that, in the case of Soay sheep, this is a phylogenetic or environmentally induced effect not immediately due to either changes to life history or adaptation to an island environment. Additionally, a comparatively short persistence time of Soay sheep on the St. Kilda archipelago might contribute to a lack of detectable changes of tooth eruption patterns. Further studies on tooth eruption in known age populations of the wild relatives of domestic sheep, which to our knowledge do not yet exist, would further help illuminate how dental development might have been influenced by changes to life history and/or adaptations to island life.

Acknowledgements The authors are grateful to Renate Schafberg (HTK), Roberto Portela Miguez (BMNH), Loïc Costeur (NMB), Josephine Pemberton (University of Edinburgh), Jerry Herman and Andrew Kitchener (NMSZ), Frank Zachos and Alexander Bibl (NMW), Steffen Bock, Peter Giere and Frieder Mayer (ZMB_Mam), and Anneke van Heteren and Michael Hiermeier (ZSM) for providing access to specimens. The authors also thank Tim Clutton-Brock (University of Cambridge) and Josephine Pemberton (University of Edinburgh) for access to Soay sheep life history data, Rachel O'Meara and Josephine Pemberton for valuable discussion, and two anonymous reviewers for providing comments to improve the manuscript, as well as John Wible for editorial work. For support of the research entailed in this paper, the authors are grateful to the Swiss National Science Foundation (P2ZHP3 171977 to MG), the University of Cambridge Department of Zoology, and the Leverhulme Trust (to RJA). We acknowledge past support from National Environment Research Council to Josephine Pemberton and Tim Clutton-Brock for Soay sheep research.

\section{Compliance with Ethical Standards}

Conflict of Interest The authors declare that they have no conflict of interest.

Open Access This article is distributed under the terms of the Creative Commons Attribution 4.0 International License (http:// creativecommons.org/licenses/by/4.0/), which permits unrestricted use, distribution, and reproduction in any medium, provided you give appropriate credit to the original author(s) and the source, provide a link to the Creative Commons license, and indicate if changes were made.

\section{References}

Adametz L (1926) Lehrbuch der allgemeinen Tierzucht. Springer, Vienna Asdell SA (1964) Patterns of Mammalian Reproduction. Constable \& Co. Ltd., London

Asher RJ, Gunnell GF, Seiffert ER, Pattinson D, Tabuce R, Hautier L, Sallam HM (2017) Dental eruption and growth in Hyracoidea (Mammalia, Afrotheria). J Vertebr Paleontol 37:e1317638. https:// doi.org/10.1080/02724634.2017.1317638

Asher RJ, Lehmann T (2008) Dental eruption in afrotherian mammals. BMC Biol 6:14. https://doi.org/10.1186/1741-7007-6-14

Asher RJ, Olbricht G (2009) Dental ontogeny in Macroscelides proboscideus (Afrotheria) and Erinaceus europaeus (Lipotyphla). 
J Mammal Evol 16:99-115. https://doi.org/10.1007/s10914-0099105-2

Behrens H, Scheelje R, Wassmuth R (1983) Lehrbuch der Schafzucht. Paul Parey, Hamburg, Berlin

Benzie D, Gill JC (1974) Radiography of the skeletal and dental condition of the Soay sheep. In: Jewell PA, Milner C, Morton Boyd J (eds) Island Survivors: The Ecology of the Soay Sheep of St. Kilda. Athlone Press, London, pp 326-337

Böhmer C, Heissig K, Rössner GE (2016) Dental eruption series and replacement pattern in Miocene Prosantorhinus (Rhinocerotidae) as revealed by macroscopy and X-ray: implications for ontogeny and mortality profile. J Mammal Evol 23:265-279. https://doi.org/ 10.1007/s10914-015-9313-x

Bover P, Alcover JA (1999) The evolution and ontogeny of the dentition of Myotragus balearicus Bate, 1909 (Artiodactyla, Caprinae): evidence from new fossil data. Biol J Linn Soc 68:401-428. https://doi. org/10.1111/j.1095-8312.1999.tb01178.x

Boyd JM, Doney JM, Gunn RG, Jewell PA (1964) The Soay sheep of the island of Hirta, St. Kilda. A study of a feral population. Proc Zool Soc Lond 142:129-164. https://doi.org/10.1111/j.1469-7998.1964. tb05159.x

Campbell RN (1974) St. Kilda and its sheep. In: Jewell PA, Milner C, Morton Boyd J (eds) Island Survivors: The Ecology of the Soay Sheep of St. Kilda. Athlone Press, London, pp 8-35

Castelló JR (2016) Bovids of the World: Antelopes, Gazelles, Cattle, Goats, Sheep, and Relatives. Princeton University Press, Princeton, Oxford

Chessa B, Pereira F, Arnaud F, Amorim A, Goyache F, Mainland I, Kao RR, Pemberton JM, Beraldi D, Stear MJ, Alberti A, Pittau M, Iannuzzi L, Banabazi MH, Kazwala RR, Zhang Y, Arranz JJ, Ali BA, Wang Z, Uzun M, Dione MM, Olsaker I, Holm L-E, Saarma U, Ahmad S, Marzanov N, Eythorsdottir E, Holland MJ, AjmoneMarsan P, Bruford MW, Kantanen J, Spencer TE, Palmarini M (2009) Revealing the history of sheep domestication using retrovirus integrations. Science 324:532-536. https://doi.org/10.1126/science. 1170587

Ciancio MR, Castro MC, Galliari FC, Carlini AA, Asher RJ (2012) Evolutionary implications of dental eruption in Dasypus (Xenarthra). J Mammal Evol 19:1-8. https://doi.org/10.1007/ s10914-011-9177-7

Clutton-Brock J (1999) A Natural History of Domesticated Mammals. Cambridge University Press, Cambridge

Clutton-Brock J, Dennis-Bryan K, Armitage PL, Jewell PA (1990) Osteology of the Soay sheep. Bull Brit Mus Nat Hist 56:1-56

Clutton-Brock TH, Grenfell BT, Coulson T, MacColl ADC, Illius AW, Forchhammer MC, Wilson K, Lindström J, Crawley MJ, Albon SD (2004a) Population dynamics in Soay sheep. In: Clutton-Brock TH, Pemberton JM (eds) Soay Sheep - Dynamics and Selection in an Island Population. Cambridge University Press, Cambridge, pp 52 88

Clutton-Brock TH, Pemberton JM (2004a) Individuals and populations. In: Clutton-Brock TH, Pemberton JM (eds) Soay Sheep - Dynamics and Selection in an Island Population. Cambridge University Press, Cambridge, pp 1-16

Clutton-Brock TH, Pemberton JM (eds) (2004b) Soay sheep - Dynamics and Selection in an Island Population. Cambridge University Press, Cambridge

Clutton-Brock TH, Pemberton JM, Coulson T, Stevenson IR, MacColl ADC (2004b) The sheep of St. Kilda. In: Clutton-Brock TH, Pemberton JM (eds) Soay Sheep - Dynamics and Selection in an Island Population. Cambridge University Press, Cambridge, pp 1751

Coulson T, Catchpole EA, Albon SD, Morgan BJT, Pemberton JM, Clutton-Brock TH, Crawley MJ, Grenfell BT (2001) Age, sex, density, winter weather, and population crashes in Soay sheep. Science 292:1528-1531. https://doi.org/10.1126/science.292.5521.1528
Davis SJM (2000) The effect of castration and age on the development of the Shetland sheep skeleton and a metric comparison between bones of males, females and castrates. J Archaeol Sci 27:373-390. https:// doi.org/10.1006/jasc.1999.0452

Doney JM, Ryder ML, Gunn RG, Grubb P (1974) Colour, conformation, affinities, fleece and patterns of inheritance in the Soay sheep. In: Jewell PA, Milner C, Morton Boyd J (eds) Island Survivors: The Ecology of the Soay Sheep of St. Kilda. Athlone Press, London, pp $88-125$

Driscoll CA, Macdonald DW, O'Brien SJ (2009) From wild animals to domestic pets, an evolutionary view of domestication. Proc Natl Acad Sci USA 106:9971-9978. https://doi.org/10.1073/pnas. 0901586106

Dýrmundsson ÓR (1981) Natural factors affecting puberty and reproductive performance in ewe lambs: a review. Livest Prod Sci 8:55-65

Egloff N (2017) ProSpecieRara - Schweizerische Stiftung für die kulturhistorische und genetische Vielfalt von Pflanzen und Tieren. https://www.prospecierara.ch. Accessed 30 Nov 2017

Feulner PGD, Gratten J, Kijas JW, Visscher PM, Pemberton JM, Slate J (2013) Introgression and the fate of domesticated genes in a wild mammal population. Mol Ecol 22:4210-4221. https://doi.org/10. $1111 /$ mec. 12378

Fraser AF (1968) Reproductive Behaviour in Ungulates. Academic Press, London, New York

Freetly HC, Leymaster KA (2004) Relationship between litter birth weight and litter size in six breeds of sheep. J Anim Sci 82:612-618

Gentry A, Clutton-Brock J, Groves CP (2004) The naming of wild animal species and their domestic derivatives. J Archaeol Sci 31:645-651. https://doi.org/10.1016/j.jas.2003.10.006

Godfrey LR, Samonds KE, Jungers WL, Sutherland MR (2001) Teeth, brains, and primate life histories. Am J Phys Anthropol 114:192214

Godfrey LR, Samonds KE, Wright PC, King SJ (2005) Schultz's unruly rule: dental developmental sequences and schedules in small-bodied, folivorous lemurs. Folia Primatol 76:77-99

Gomes Rodrigues H, Herrel A, Billet G (2017) Ontogenetic and life history trait changes associated with convergent ecological specializations in extinct ungulate mammals. Proc Natl Acad Sci USA 114: 1069-1074. https://doi.org/10.1073/pnas.1614029114

Groves CP (1989) Feral mammals of the Mediterranean islands: documents of early domestication. In: The Walking Larder: Patterns of Domestication, Partoralism, and Predation. Routledge, London, New York, pp 22-27

Grubb P (1974) Population dynamics of the Soay sheep. In: Jewell PA, Milner C, Morton Boyd J (eds) Island Survivors: The Ecology of the Soay Sheep of St. Kilda. Athlone Press, London, pp 242-272

Gulland FMD (1992) The role of nematode parasites in Soay sheep (Ovis aries L.) mortality during a population crash. Parasitology 105:493503

Guthrie EH, Frost SR (2011) Pattern and pace of dental eruption in Tarsius. Am J Phys Anthropol 145:446-451. https://doi.org/10. 1002/ajpa.21525

Habermehl K-H (1975) Die Altersbestimmung bei Haus- und Labortieren. Paul Parey, Berlin, Hamburg

Habermehl K-H (1985) Altersbestimmung bei Wild- und Pelztieren. Paul Parey, Hamburg, Berlin

Hafez ESE (1952) Studies on the breeding season and reproduction of the ewe: Part I. The breeding season in different environments, Part II. The breeding season in one locality. J Agric Sci 42:189-231

Hammer Ø, Harper DAT, Ryan PD (2001) PAST: paleontological statistics software package for education and data analysis. Palaeontol Electron 4:1-9

Haring F, Brüne C, Dedié K, Gruhn R, Smidt D (1984) Schafzucht. Eugen Ulmer, Stuttgart 
Harris RB, Reading R (2008) Ovis ammon. The IUCN Red List of Threatened Species. http://www.iucnredlist.org/details/15733/0. Accessed 30 Nov 2017

Henderson E (2007) Platyrrhine dental eruption sequences. Am J Phys Anthropol 134:226-239. https://doi.org/10.1002/ajpa.20658

Hiendleder S, Kaupe B, Wassmuth R, Janke A (2002) Molecular analysis of wild and domestic sheep questions current nomenclature and provides evidence for domestication from two different subspecies. Proc R Soc B Biol Sci 269:893-904

Janis CM, Fortelius M (1988) On the means whereby mammals achieve increased functional durability of their dentitions, with special reference to limiting factors. Biol Rev 63:197-230. https://doi.org/10. 1111/j.1469-185X.1988.tb00630.x

Jewell PA, Grubb P (1974) The breeding cycle, the onset of oestrus and conception in Soay sheep. In: Jewell PA, Milner C, Morton Boyd J (eds) Island Survivors: The Ecology of the Soay sheep of St. Kilda. Athlone Press, London, pp 224-241

Jewell PA, Milner C, Morton Boyd J (eds) (1974) Island Survivors: The Ecology of the Soay Sheep of St. Kilda. Athlone Press, London

Jogahara YO, Natori M (2012) Dental eruption sequence and eruption times in Erythrocebus patas. Primates 53:193-204. https://doi.org/ 10.1007/s10329-011-0286-y

Jones GG (2002) Tooth eruption and wear observed in live sheep from Butser Hill, the Cotswold Farm Park and five farms in the Pentland Hills, UK. In: Ruscillo D (ed) Recent Advances in Ageing and Sexing Animal Bones. Oxbow, Durham, pp 155-178

Jordana X, Köhler M (2011) Enamel microstructure in the fossil bovid Myotragus balearicus (Majorca, Spain): implications for life-history evolution of dwarf mammals in insular ecosystems. Palaeogeogr Palaeoclimatol Palaeoecol 300:59-66. https://doi.org/10.1016/j. palaeo.2010.12.008

Jordana X, Marín-Moratalla N, DeMiguel D, Kaiser TM, Köhler M (2012) Evidence of correlated evolution of hypsodonty and exceptional longevity in endemic insular mammals. Proc R Soc B 279: 3339-3346. https://doi.org/10.1098/rspb.2012.0689

Jordana X, Marín-Moratalla N, Moncunill-Solé B, Bover P, Alcover JA, Köhler M (2013) First fossil evidence for the advance of replacement teeth coupled with life history evolution along an anagenetic mammalian lineage. PLoS One 8:e70743. https://doi.org/10.1371/ journal.pone. 0070743

Kierdorf H, Kierdorf U, Frölich K, Witzel C (2013) Lines of evidence incremental markings in molar enamel of Soay sheep as revealed by a fluorochrome labeling and backscattered electron imaging study. PLoS One 8:e74597. https://doi.org/10.1371/journal.pone.0074597

Köhler M, Moyà-Sola S (2009) Physiological and life history strategies of a fossil large mammal in a resource-limited environment. Proc Natl Acad Sci USA 106:20354-20358. https://doi.org/10.1073/pnas. 0813385106

Köhler M, Moyà-Solà S (2004) Reduction of brain and sense organs in the fossil insular bovid Myotragus. Brain Behav Evol 63:125-140. https://doi.org/10.1159/000076239

Lalueza-Fox C, Castresana J, Sampietro L, Marquès-Bonet T, Alcover JA, Bertranpetit J (2005) Molecular dating of caprines using ancient DNA sequences of Myotragus balearicus, an extinct endemic Balearic mammal. BMC Evol Biol 5:1-11. https://doi.org/10.1186/ 1471-2148-5-70

Larson G, Piperno DR, Allaby RG, Purugganan MD, Andersson L, Arroyo-Kalin M, Barton L, Climer Vigueira C, Denham T, Dobney K, Doust AN, Gepts P, Gilbert MTP, Gremillion KJ, Lucas L, Lukens L, Marshall FB, Olsen KM, Pires JC, Richerson PJ, Rubio de Casas R, Sanjur OI, Thomas MG, Fuller DQ (2014) Current perspectives and the future of domestication studies. Proc Natl Acad Sci USA 111:6139-6146. https://doi.org/10.1073/pnas. 1323964111

Lincoln GA, Lincoln CE, McNeilly AS (1990) Seasonal cycles in the blood plasma concentration of FSH, inhibin and testosterone, and testicular size in rams of wild, feral and domesticated breeds of sheep. J Reprod Fertil 88:623-633

Marín-Moratalla N, Jordana X, García-Martínez R, Köhler M (2011) Tracing the evolution of fitness components in fossil bovids under different selective regimes. C R Palevol 10:469-478. https://doi.org/ 10.1016/j.crpv.2011.03.007

McCance RA, Ford EHR, Brown WAB (1961) Severe undernutrition in growing and adult animals: 7. Development of the skull, jaws and teeth in the pigs. Brit J Nutr 15:213-224

Milner C, Gwynne D (1974) The Soay sheep and their food supply. In: Jewell PA, Milner C, Morton Boyd J (eds) Island Survivors: The Ecology of the Soay Sheep of St. Kilda. Athlone Press, London, pp 273-325

Monson TA, Hlusko LJ (2016) The evolution of dental eruption sequence in artiodactyls. J Mammal Evol 25:15-26. https://doi.org/10.1007/ s10914-016-9362-9

Moran NC, O'Connor TP (1994) Age attribution in domestic sheep by skeletal and dental maturation: a pilot study of available sources. Internatl J Osteoarchaeol 4:267-285. https://doi.org/10.1002/oa. 1390040402

Morton Boyd J, Jewell PA (1974) The Soay sheep and their environment: a synthesis. In: Jewell PA, Milner C, Morton Boyd J (eds) Island Survivors: The Ecology of the Soay Sheep of St. Kilda. Athlone Press, London, pp 360-373

Nacarino-Meneses C, Jordana X, Orlandi-Oliveras G, Köhler M (2017) Reconstructing molar growth from enamel histology in extant and extinct Equus. Sci Rep 7:15965. https://doi.org/10.1038/s41598$017-16227-2$

O'Meara RN, Dirks W, Martinelli AG (2018) Enamel formation and growth in non-mammalian cynodonts. R Soc Open Sci 5:172293. https://doi.org/10.1098/rsos.172293

Ozgul A, Tuljapurkar S, Benton TG, Pemberton JM, Clutton-Brock TH, Coulson T (2009) The dynamics of phenotypic change and the shrinking sheep of St. Kilda. Science 325:464 467. https://doi.org/ 10.1126/science. 1173668

Palkovacs EP (2003) Explaining adaptive shifts in body size on islands: a life history approach. Oikos 103:37-44. https://doi.org/10.1034/j. 1600-0706.2003.12502.x

Pedrosa S, Uzun M, Arranz J-J, Gutiérrez-Gil B, San Primitivo F, Bayón Y (2005) Evidence of three maternal lineages in Near Eastern sheep supporting multiple domestication events. Proc R Soc B 272:22112217. https://doi.org/10.1098/rspb.2005.3204

Popkin PR, Baker P, Worley F, Payne S, Hammond A (2012) The Sheep Project (1): determining skeletal growth, timing of epiphyseal fusion and morphometric variation in unimproved Shetland sheep of known age, sex, castration status and nutrition. J Archaeol Sci 39: 1775-1792. https://doi.org/10.1016/j.jas.2012.01.018

Raia P, Barbera C, Conte M (2003) The fast life of a dwarfed giant. Evol Ecol 17:293-312

Reznick DN, Bryant MJ, Bashey F (2002) r- and K-selection revisited: the role of population regulation in life-history evolution. Ecology 83:1509-1520. https://doi.org/10.1890/0012-9658(2002)083[1509: RAKSRT]2.0.CO;2

Rosa HJD, Bryant MJ (2003) Seasonality of reproduction in sheep. Small Rumin Res 48:155-171. https://doi.org/10.1016/S0921-4488(03) 00038-5

Sambraus HH (2016) Farbatlas Nutztierrassen. Eugen Ulmer, Stuttgart

Sánchez-Villagra MR, Geiger M, Schneider RA (2016) The taming of the neural crest: a developmental perspective on the origins of morphological covariation in domesticated mammals. R Soc Open Sci 3: 160107. https://doi.org/10.1098/rsos. 160107

Schaller GB (1977) Mountain Monarchs - Wild Sheep and Goats of the Himalaya. University of Chicago Press, Chicago, London

Schultz AH (1956) Postembryonic age changes. In: Hofer H, Schultz AH, Starck D (eds) Primatologia. Karger, Basel, pp 887-964 
Schultz AH (1960) Age changes in primates and their modifiction in man. In: Tanner JM (ed) Human Growth. Pergamon Press, Oxford, pp 120

Schwartz GT, Mahoney P, Godfrey LR, Cuozzo FP, Jungers WL, Randria GFN (2005) Dental development in Megaladapis edwardsi (Primates, Lemuriformes): implications for understanding the lifehistory variation in subfossil lemurs. J Hum Evol 49:702-721

Silver IA (1963) The aging of domestic animals. In: Brothwell D, Higgs E (eds) Science in Archaeology: A Comprehensive Survey of Progress and Research. Basic Books, New York, pp 250-268

Smith BH (2000) "Schultz's Rule" and the evolution of tooth emergence and replacement patterns in primates and ungulates. In: Teaford MF, Smith MM, Ferguson MWJ (eds) Development, Function and Evolution of Teeth. Cambridge University Press, Cambridge, pp 212-227

Sondaar PY (1977) Insularity and its effect on mammal evolution. In: Hecht MK, Goody PC, Hecht BM (eds) Major Patterns in Vertebrate Evolution. Plenum Press, New York, pp 671-707

Stevenson IR, Marrow P, Preston BT, Pemberton JM, Wilson K (2004) Adaptive reproductive strategies. In: Clutton-Brock TH, Pemberton JM (eds) Soay Sheep - Dynamics and Selection in an Island Population. Cambridge University Press, Cambridge, pp 243-275

Tacutu R, Craig T, Budovsky A, Wuttke D, Lehmann G, Taranukha D, Costa J, Fraifeld VE, de Magalhães JP (2013) Human Ageing Genomic Resources: integrated databases and tools for the biology and genetics of ageing. Nucleic Acids Res 41:D1027-D1033

Tchernov E, Horwitz LK (1991) Body size diminution under domestication: unconscious selection in primeval domesticates. J Anthropol Archaeol 10:54-75. https://doi.org/10.1016/0278-4165(91)90021$\mathrm{O}$

Ungar PS (2010) Mammal Teeth: Origin, Evolution, and Diversity. Johns Hopkins University Press, Baltimore
Valdez R (2008) Ovis orientalis. The IUCN Red List of Threatened Species. http://www.iucnredlist.org/details/15739/0. Accessed 30 Nov 2017

Valdez R (1976) Fecundity of wild sheep (Ovis orientalis) in Iran. J Mammal 57:762-763

van der Geer A, Lyras G, de Vos J, Dermitzakis M (2010) Evolution of Island Mammals: Adaptation and Extinction of Placental Mammals on Islands. Wiley-Blackwell, Chichester

Veitschegger K, Kolb C, Amson E, Sánchez-Villagra MR (2018) Longevity and life history of cave bears - a review and novel data from tooth cementum and relative emergence of permanent dentition. Hist Biol 1-7. https://doi.org/10.1080/08912963.2018. 1441293

Veitschegger K, Sánchez-Villagra MR (2016) Tooth eruption sequences in cervids and the effect of morphology, life history, and phylogeny. J Mammal Evol 23:251-263. https://doi.org/10.1007/s10914-0159315-8

Wilson DE, Reeder DM (eds) (2005) Mammal Species of the World: A Taxonomic and Geographic Reference. Johns Hopkins University Press, Baltimore

Wilson K, Grenfell BT, Pilkington JG, Boyd HEG, Gulland FMD (2004) Parasites and their impact. In: Clutton-Brock TH, Pemberton JM (eds) Soay Sheep - Dynamics and Selection in an Island Population. Cambridge University Press, Cambridge, pp 113-165

Worley F, Baker P, Popkin P, Hammon A, Payne S (2016) The Sheep Project (2): the effects of plane of nutrition, castration and the timing of first breeding in ewes on dental eruption and wear in unimproved Shetland sheep. J Archaeol Sci Reports 6:862-874. https://doi.org/ 10.1016/j.jasrep.2015.10.029

Zeder MA (2002) Reconciling rates of long bone fusion and tooth eruption and wear in sheep (Ovis) and goat (Capra). In: Ruscillo D (ed) Recent Advances in Ageing and Sexing Animal Bones. Oxbow, Durham, pp 87-118 